\title{
Precision Analysis of Poisson Control Chart Based on Sample Size
}

\section{Analisis Keakuratan Bagan Kendali Poisson Berdasarkan Ukuran Sampel}

\author{
Elsa Resa Sari ${ }^{1}$, Erna Tri Herdiana ${ }^{2}$, Nasrah Sirajang ${ }^{3}$
}

\begin{abstract}
One technique used in performing statistical quality control is by poisson control chart. Poisson control chart used in data that have the same mean and varians for monitoring the number of defects in the study. In some cases, the different sample sizes influence the control chart performance. The control chart performance can be measured using average run length (ARL). The smaller ARL's value, the better type of control chart. In this study, we used different sample sizes that is $m=\{10,20,50,100,200\}$ and mean $c_{0}=\{5,10,15,30,50,70,100\}$. The result show the best performance of control chart is when $c_{0}=5$ and $\mathrm{m}=200$, because its has a smaller ARL's value.
\end{abstract}

Keywords: Poisson control chart, attribute control chart, ARL .

\begin{abstract}
Abstrak
Salah satu teknik yang digunakan dalam melakukan pengendalian kualitas statistik yaitu dengan bagan kendali poisson. Bagan kendali poisson adalah bagan kendali yang digunakan pada data yang memiliki mean dan variansi yang sama untuk memonitor jumlah kecacatan dalam penelitian. Dalam beberapa kasus, jumlah ukuran sampel berpengaruh pada kinerja bagan kendali. Kinerja bagan pengendali dapat diukur menggunakan Average Run Length (ARL). Semakin kecil nilai ARL maka semakin baik jenis bagan kendali yang bersangkutan. Pada penelitian ini menggunakan ukuran sampel yang berbeda yaitu $m=\{10,20,50,100,200\}$ dan mean $c_{0}=\{5,10,15,30,50,70,100\}$. Hasil penelitian menunjukkan kinerja bagan kendali poisson yang paling bagus untuk ukuran sampel yang berbeda yaitu pada saat $c_{0}=5$ dan $\mathrm{m}=200$ karena memiliki nilai ARL yang terkecil.
\end{abstract}

Kata kunci: Bagan kendali poisson, Bagan kendali atribut c, ARL, . 


\section{Elsa Resa Sari, Erna Tri Herdiana, Nasrah Sirajang}

\section{Pendahuluan}

Salah satu bagan kendali atribut yang digunakan sebagai monitor jumlah kecacatan tiap unit produk adalah bagan kendali c dan bagan kendali u. Bagan kendali c yang berarti "count" atau hitung cacat digunakan untuk menghitung banyaknya cacat dalam sampel dan prosedur pemeriksaan harus sama untuk setiap sampel dan dilakukan secara konsisten dari sampel ke sampel [13]. Sedangkan bagan kendali u berarti "unit" cacat dalam kelompok sampel. Bagan kendali u digunakan untuk menghitung titik cacat per unit laporan pemeriksaan dalam periode yang mungkin memiliki ukuran sampel bervariasi. Jika pada bagan kendali c, kita langsung memplotkan data cacat ke dalam bagan kendali, maka pada bagan kendali u kita perlu menghitung terlebih dahulu u cacat untuk setiap n sampel.

Pendekatan bagan kendali atribut c akan diaplikasikan pada kasus penderita penyakit Demam Berdarah Dengue (DBD). Penyakit DBD adalah yang disebabkan oleh virus dengue ditularkan kepada manusia melalui gigitan nyamuk Aedes Aegypti dan Aedes Albocpictus. Gejala yang akan muncul seperti ditandai dengan demam mendadak, sakit kepala, nyeri belakang bola mata, mual, dan menifestasi pendarahan seperti mimisan atau gusi berdarah serta adanya kemerahan dibagian permukaan tubuh pada penderita (Kementerian Kesehatan RI, 2015).

Asumsi yang sangat diperlukan untuk pengembangan bagan kendali adalah distribusi parameter proses diasumsikan diketahui. Dalam prakteknya, distribusi data proses parameter jarang diketahui. Oleh karena itu, parameter dapat ditaksir berdasarkan data historis dalam tahap 1 [3]. Salah satu cara untuk mengukur kinerja bagan kendali adalah dengan menggunakan Average Run Length (ARL). Semakin kecil nilai ARL maka semakin baik jenis bagan kendali yang bersangkutan [13]. Beberapa penelitian terdahulu yang terkait dengan kinerja bagan kendali berdasarkan ARL diantaranya Parameter Estimation and Performance of The p-Chart For Attributes Data [4], dan Design of The C and NP Charts When The Parameters Are Estimated [3], dan Perbandingan Peta Kendali Atribut Dalam Pengendalian Kualitas Produk di PT. Arika Kharisma Agung [1]. Sehingga pada penelitian ini bertujuan untuk menganalisis keakuratan bagan kendali poisson berdasarkan ukuran sampel.

\section{Tinjauan Pustaka}

\subsection{Pengendalian Kualitas}

Pengendalian kualitas secara statistik dengan menggunakan SPC (Statistical Processing Control) mempunyai 7 alat statistik utama yang dapat digunakan sebagai alat bantu untuk mengendalikan kualitas, antara lain yaitu; check Sheet, histogram, control chart, diagram pareto, diagam sebab akibat, scatter diagram, dan diagram proses. 


\section{Elsa Resa Sari, Erna Tri Herdiana, Nasrah Sirajang}

\subsection{Bagan Kendali}

Bagan kendali adalah teknik pengendali proses pada jalur yang digunakan secara luas yang biasanya digunakan untuk menaksir parameter suatu proses produksi, menentukan kemampuan dan memberikan informasi yang berguna dalam meningkatkan proses produksi [12].

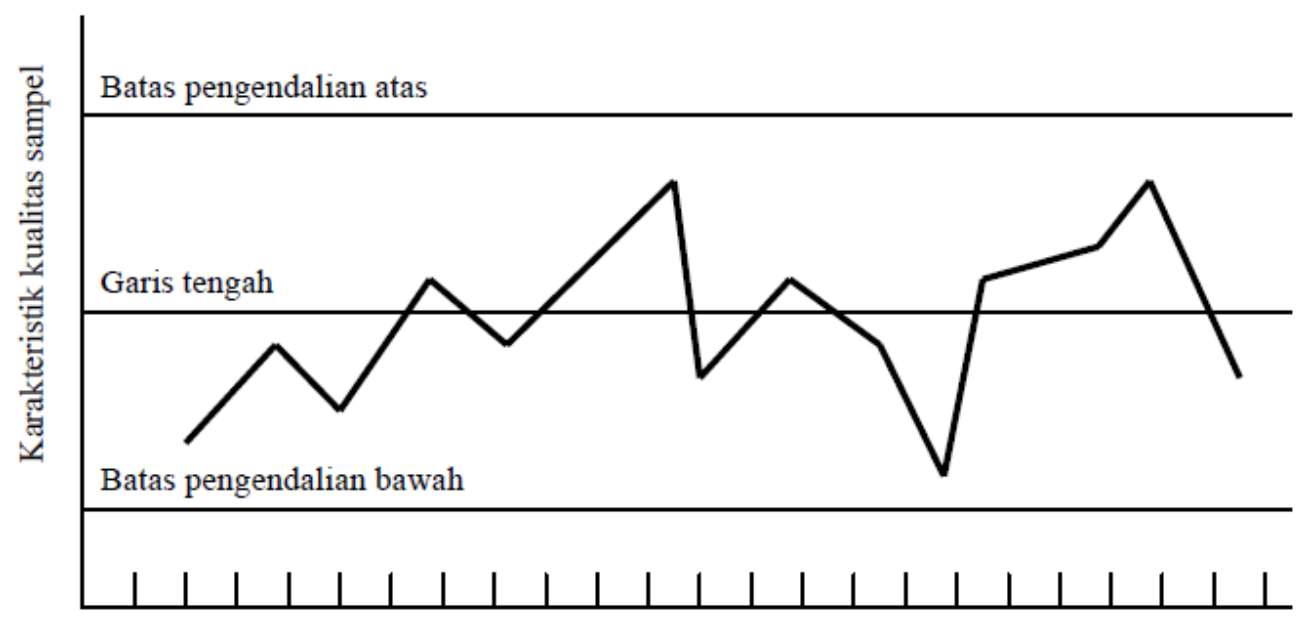

Nomor sample atau waktu

Gambar 2.1 Bentuk Dasar Bagan Kendali

(Sumber : Tugas Akhir Hilmi Faizah, 2012).

Bentuk dasar bagan kendali seperti ditunjukkan pada gambar diatas yang merupakan peragaan grafik suatu karakteristik kualitas yang telah diukur atau dihitung dari sampel terhadap nomor sampel atau waktu [12].

\subsection{Distribusi Poisson}

Distribusi Poisson adalah distribusi peluang peubah acak $X$, yang menyatakan banyaknya sukses yang terjadi dalam suatu selang waktu atau daerah tertentu, $X$ disebut berdistribusi Poisson jika memenuhi tiga dalil berikut :

a. Independence : banyaknya sukses yang terjadi pada waktu tertentu saling independent dengan banyaknya sukses pada waktu yang lain.

b. Lack of Clustering : kesempatan terdapat dua atau lebih kejadian yang terjadi secara berurutan dapat diasumsikan 0 .

c. Rate : rata-rata jumlah kejadian setiap satuan waktu adalah konstan, dinyatakan dengan $m$, dan tidak berubah oleh waktu. 


\section{Elsa Resa Sari, Erna Tri Herdiana, Nasrah Sirajang}

\subsection{Uji Distribusi Poisson}

Uji Distribusi Poisson dilakukan untuk melihat apakah data berdistribusi Poisson. Hal ini dikarenakan untuk dapat mengevaluasi proses menggunakan bagan kendali c maka asumsi data berdistribusi Poisson harus dipenuhi.

Hipotesis yang digunakan.

$\mathrm{H}_{0}: \mathrm{F}_{0(\mathrm{x})}=\mathrm{F}_{(\mathrm{x})}$, untuk semua nilai $\mathrm{x}$.

$\mathrm{H}_{1}: \mathrm{F}_{\mathrm{O}(\mathrm{x})} \neq \mathrm{F}_{(\mathrm{x})}$, untuk sekurang-kurangnya sebuah nilai $\mathrm{x}$.

Dimana

$\mathrm{F}_{0(\mathrm{x})}=$ fungsi ditribusi yang dihipotesiskan (berdistribusi Poisson).

$F_{(x)}=$ fungsi distribusi yang belum diketahui.

Statistik uji yang digunakan adalah :

$$
x^{2}=\sum_{i=1}^{k} \frac{\left(O_{i}-E_{i}\right)^{2}}{E_{i}}
$$

Dimana :

$k=$ banyaknya kategori

$O_{i}=$ hasil pengamatan untuk kategori ke-i

$E_{i}=$ hasil yang diharapkan (ekspektasi) untuk kategori ke-i.

Keputusan $\mathrm{H}_{0}$ diterima pada taraf nyata $\alpha$ jika $x^{2}<x_{\text {tabel(r-1) }}^{2}$ atau $\mathrm{P}-$ value $>\alpha$ yang artinya data berdistribusi Poisson [14].

\subsection{Bagan Kendali Atribut C}

Menurut [5] dalam beberapa situasi ketika jumlah rata-rata cacat yang sebenarnya dalam unit inspeksi c tidak diketahui atau tidak spesifik. Hal ini dapat muncul, misalnya proses baru dimulai dan tidak banyak data yang tersedia. Hal seperti ini disebut sebagai kasus standar yang tidak diketahui. Dalam kasus ini, sangat umum untuk memperkirakan $\mathrm{C}$ dari satu set data, biasanya dari $m$ unit inspeksi independen (terpisah), diambil ketika prosesnya dianggap terkendali. Seperangkat data semacam itu disebut sebagai data referensi atau data Tahap 1, dan fase analisis ini disebut fase retrospektif. Misalkan, data terdiri dari $i=1, \ldots, m$ sampel $\left\{X_{i, 1}, \ldots, X_{i, n}\right\}$ yang berukuran $n$. Kita asumsikan terdapat sampel bebas diantara beberapa sampel, dan $X_{i}=\sum_{j=1}^{n} X_{i, j} \sim P(c)$ yaitu berdistribusi Poisson dengan parameter $c$. Untuk menghitung jumlah rata-rata cacat per unit, maka digunakan rumus sebagai berikut :

$$
\bar{c}=\frac{1}{m} \sum_{i=1}^{m} X_{i}=\frac{X}{m}
$$




\section{Elsa Resa Sari, Erna Tri Herdiana, Nasrah Sirajang}

Perhatikan bahwa variabel acak $X$ menunjukkan jumlah total ketidaksesuaian diseluruh unit inspeksi m yang diperoleh pada tahap 1. Batas kontrol dari bagan kendali c adalah

$$
\begin{aligned}
& B P A_{c}=[\bar{c}+K \sqrt{\bar{c}}] \\
& G T_{c}=\bar{c} \\
& B P B_{c}=[\bar{c}-K \sqrt{\bar{c}}]
\end{aligned}
$$

Dengan $\bar{c}$ adalah jumlah rata-rata cacat per unit. Jika BPB bernilai negatif, maka BPB dijadikan sama dengan nol.

\subsection{Average Run Length (ARL)}

Kriteria yang digunakan untuk dapat membandingkan bagan kendali adalah dengan mengukur seberapa cepat bagan kendali tersebut membangkitkan sinyal out of control. Bagan kendali yang lebih cepat mendeteksi sinyal out of control disebut lebih sensitif terhadap perubahan proses [8]. Salah satu cara untuk mengukur kinerja bagan kendali adalah dengan menggunakan average run length (ARL).

ARL adalah rata-rata jumlah titik sampel yang harus digambarkan sebelum satu titik menunjukkan keadaan tidak terkendali [13]. ARL dinyatakan sebagai :

$$
A R L=\frac{1}{P(\text { suatu titik diluar kendali })}
$$

Misalkan $\alpha$ merupakan $\mathrm{P}$ (suatu titik diluar kendali), maka perumusan untuk ARL dalam keadaan terkendali adalah :

$$
A R L_{0}=\frac{1}{\alpha}
$$

atau

$$
A R L_{1}=\frac{1}{1-\beta}
$$

\section{Metode Analisis}

Data yang digunakan dalam penelitian ini adalah data simulasi dan data riil. Data simulasi didapatkan melalui membangkitkan data dengan menggunakan MINITAB. Data simulasi ini dibangkitkan menggunakan parameter mean $c_{0}$ yang berdistribusi Poisson dengan ukuran sampel yang dipilih yaitu $m=\{10,20,50,100,200\}$ dan mean $c_{0}=\{5,10,15,30,50,70,100\}$.

Data riil yang digunakan pada penelitian ini adalah data sekunder yang diambil dari penelitian yang dilakukan oleh Firmina Adlaida (2011) yang berumur 25 tahun ke bawah yang pernah 


\section{Elsa Resa Sari, Erna Tri Herdiana, Nasrah Sirajang}

menjalani rawat inap di RS. Wahidin Sudirohusodo periode bulan Januari 2005 sampai bulan Juli 2006.

Tahapan yang dilakukan dalam penelitian ini adalah sebagai berikut :

Tahap I menggunakan data simulasi

1. Membangkitkan data dengan menetapkan parameter $c_{0}$ dengan nilai $c_{0}=\{5,10,15,30,50,70,100\}$ untuk masing-masing sampel yang berukuran $m=$ $\{10,20,50,100,200\}$.

2. Menghitung nilai garis tengah, BPA, dan BPB untuk masing-masing sampel pada bagan kendali c menggunakan Pers. (2.8)

3. Menghitung nilai distribusi Poisson kumulatif untuk BPA dan BPB menggunakan Excel dengan rumus

$$
P(B P A) \text { atau } P(B P B)=\text { poisson }(x, \text { mean }, \text { cumulative })
$$

4. Menghitung probabilitas error type II dengan rumus

$$
\beta=P(x<B P A \mid c)-P(x \leq B P B \mid c)
$$

5. Menghitung average run length (ARL) menggunakan rumus

$$
A R L=\frac{1}{1-\beta}
$$

6. Melakukan perbandingan terhadap nilai ARL yang diperoleh pada masing-masing ukuran sampel.

7. Menarik kesimpulan dari hasil dan pembahasan.

Tahap II menggunakan data asli

1. Melakukan pengujian Distribusi Poisson pada data lama rawat inap pasien.

$\mathrm{H}_{0}: \mathrm{F}_{0(\mathrm{x})}=\mathrm{F}_{(\mathrm{x})}$, untuk semua nilai $\mathrm{x}$.

$\mathrm{H}_{1}: \mathrm{F}_{0(\mathrm{x})} \neq \mathrm{F}_{(\mathrm{x})}$, untuk sekurang-kurangnya sebuah nilai $\mathrm{x}$

dimana

$\mathrm{F}_{0(\mathrm{x})}=$ fungsi distribusi yang dihipotesiskan yaitu berdistribusi Poisson

$F_{(x)}=$ fungsi distribusi yang belum diketahui

Maka statistik uji yang digunakan yaitu

$$
x^{2}=\sum_{i=1}^{k} \frac{\left(O_{i}-E_{i}\right)^{2}}{E_{i}}
$$




\section{Elsa Resa Sari, Erna Tri Herdiana, Nasrah Sirajang}

dimana :

$k$ = banyaknya kategori

$O_{i}=$ hasil pengamatan untuk kategori ke-i

$E_{i}=$ hasil yang diharapkan (ekspektasi) untuk kategori ke-i.

Kriteria pengambilan keputusan :

$$
\left\{\begin{array}{l}
\text { Terima } H_{0} \text {, jika } \chi_{\text {hitung }}^{2}<\chi_{\text {tabel }}^{2} \text { atau } P-\text { value }>\alpha \\
\text { Tolak } H_{0} \text {, jika } \chi_{\text {hitung }}^{2}>\chi_{\text {tabel }}^{2} \text { atau } P-\text { value }<\alpha
\end{array}\right.
$$

2. Membuat bagan kendali atribut $\mathrm{C}$ dengan menghitung garis tengah, batas pengendali atas, dan batas pengendali bawah menggunakan rumus

$\bar{c}=\frac{1}{m} \sum_{i=1}^{m} X_{i}=\frac{X}{m}$

$B P A_{c}=[\bar{c}+K \sqrt{\bar{c}}]$

$B P B_{C}=[\bar{c}-K \sqrt{\bar{c}}]$

3. Melakukan analisis terhadap data untuk mengetahui apakah proses terkendali atau tidak dengan menggunakan bagan kendali atribut C. Apabila terdapat titik atau sampel yang berada diluar BPA atau BPB, maka prosesnya dikatakan tidak terkendali atau pada kasus ini dikatakan cacat.

4. Ulangi langkah ke-2 jika terdapat sampel yang berada diluar batas kendali dengan menghilangkan sampel tersebut.

5. Menarik kesimpulan dari hasil dan pembahasan.

\section{Hasil dan Pembahasan}

\subsection{Menentukan parameter $\lambda$ menggunakan Metode Momen}

Misalkan $x_{1}, x_{2}, \ldots, x_{n}$ adalah sampel acak berdistribusi Poisson dengan parameter $c$ ditulis $P(c)$.

Pada tahap I data ke-i, $i=1,2, \ldots, m$ dinotasikan sebagai $\left\{X_{i, 1}, \ldots, X_{i, n}\right\}$. Selanjutnya diasumsikan sampel saling bebas dan $X_{i}=\sum_{j=1}^{n} X_{i, j} \sim P(c)$. Estimasi dari $\lambda$ dilambangkan dengan $\hat{\lambda}$ yaitu

$$
\hat{\lambda}=\frac{1}{m} \sum_{i=1}^{m} x_{i}=\bar{X}
$$

Berdasarkan Peta Kendali Shewart batas kontrol untuk bagan kendali C

$$
B P A_{c}=\mu_{x}+K \sqrt{\sigma_{x}^{2}}
$$




$$
B P B_{c}=\mu_{x}-K \sqrt{\sigma_{x}^{2}}
$$

Karena $\mu_{x}=\bar{X}$ dan $\sigma_{x}{ }^{2}=\bar{X}$, sehingga

$$
\begin{aligned}
& B P A_{c}=[\bar{X}+K \sqrt{\bar{X}}] \\
& B P B_{c}=[\bar{X}-K \sqrt{\bar{X}}]
\end{aligned}
$$

\subsection{Studi Kasus I}

\subsubsection{Perhitungan Average Run Length}

Data simulasi didapatkan melalui membangkitkan data dengan menggunakan MINITAB. Data simulasi ini dibangkitkan menggunakan parameter mean $c_{0}$ yang berdistribusi Poisson dengan ukuran sampel yang dipilih yaitu $m=\{10,20,50,100,200\}$ dan mean $c_{0}=\{5,10,15,30,50,70,100\}$. Dengan bantuan Excel didapatkan nilai ARL untuk $m=\{10,20,50,100,200\}$ dan mean $c_{0}=\{5,10,15,30,50,70,100\}$ yang dapat dilihat pada Tabel 4.1 sebagai berikut

Tabel 4.1 Nilai ARL bagan kendali $C$ untuk $c_{0}=\{5,10,15,30,50,70,100\}$ dan $m=$ $\{10,20,50,100,200\}$.

\begin{tabular}{|c|c|c|c|c|c|}
\hline $\boldsymbol{c}_{\mathbf{0}}$ & $\mathbf{m}=\mathbf{1 0}$ & $\mathbf{m}=\mathbf{2 0}$ & $\mathbf{m}=\mathbf{5 0}$ & $\mathbf{m}=\mathbf{1 0 0}$ & $\mathbf{m}=\mathbf{2 0 0}$ \\
\hline 5 & 134.482 & 114.197 & 82.0275 & 48.9399 & 25.9296 \\
\hline 10 & 833.9938 & 612.1223 & 285.7354 & 138.2762 & 69.81771 \\
\hline 15 & 582.2878 & 156.3408 & 87.90313 & 51.27184 & 30.5031 \\
\hline 30 & 349.9398 & 242.4091 & 155.3685 & 100.9806 & 100.9806 \\
\hline 50 & 403.151 & 396.703 & 287.2535 & 206.3937 & 216.9459 \\
\hline 70 & 447.6028 & 360.4687 & 316.5384 & 240.1356 & 254.0843 \\
\hline 100 & 298.7899 & 270.9436 & 225.3211 & 181.0635 & 141.0211 \\
\hline
\end{tabular}

Sumber : Data diolah, 2019

Berdasarkan Tabel 4.1 terlihat bahwa nilai ARL terkecil untuk ukuran sampel berbeda yaitu pada saat $c_{0}=5$ dan $m=200$. Sehingga dapat disimpulkan bahwa kinerja bagan kendali yang paling bagus untuk ukuran sampel yang berbeda yaitu pada saat $c_{0}=5 \mathrm{dan} m=200$. 


\section{Elsa Resa Sari, Erna Tri Herdiana, Nasrah Sirajang}

\subsection{Studi Kasus II}

Pada bagian ini menggunakan data penderita penyakit DBD yang berumur 25 tahun ke bawah yang pernah menjalani rawat inap di RS. Wahidin Sudirohusodo periode bulan Januari 2005 sampai bulan Juli 2006.

\subsubsection{Uji Distribusi Poisson}

Digunakan uji asumsi distribusi Poisson dengan menggunakan SPSS untuk mengetahui apakah data pada penelitian ini yaitu data penderita penyakit Demam Berdarah (DBD) di RS. Wahidin Sudirohusodo memenuhi asumsi distribusi Poisson atau tidak. Hasil pengujian dapat dilihat pada Tabel 4.2.

Tabel 4.2 Uji Poisson Data Lama Rawat Inap

\begin{tabular}{|c|c|}
\hline Metode & Lama Rawat Inap (X) \\
\hline P-value & 0.251 \\
\hline
\end{tabular}

Dari Tabel 4.2 dapat dilihat bahwa nilai $P$-value untuk variabel lama rawat inap pasien adalah 0.251, dan dengan menggunakan taraf signifikansi sebesar 5\%. Sesuai dengan hipotesis uji distribusi Poisson bahwa $H_{0}$ diterima apabila $P$-value $>\alpha$, maka diperoleh keputusan bahwa $H_{0}$ diterima karena $0.251>0.05$. Sehingga dapat disimpulkan bahwa data penderita penyakit DBD di RS. Wahidin Sudirohusodo pada bulan Januari 2005 sampai bulan Juli 2006 memenuhi asumsi distribusi Poisson.

\subsubsection{Aplikasi Bagan Kendali Atribut C pada Data Riil}

Diketahui bahwa terdapat 119 sampel dengan jumlah keseluruhan lama rawat inap pasien adalah 603 hari. Bagan kendali atribut $C$ yang terbentuk adalah sebagai berikut 


\section{Elsa Resa Sari, Erna Tri Herdiana, Nasrah Sirajang}

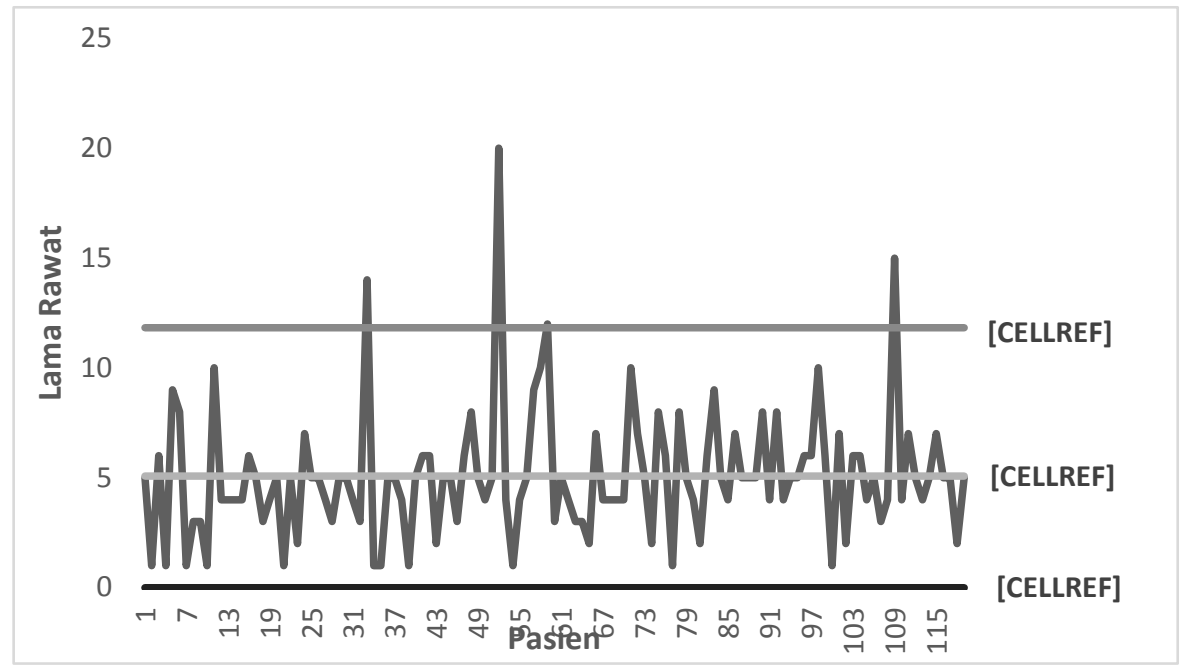

Gambar 4.4 Bagan Kendali C pada data lama rawat inap pasien penyakit DBD di RS. Wahidin Sudirohusodo.

Dari Gambar 4.4 dapat diketahui bahwa pasien penderita penyakit demam berdarah di RS. Wahidin Sudirohusodo dapat dirawat maksimal 12 hari, dan normalnya pasien penyakit demam berdarah dirawat selama kurang lebih 5 hari. Dalam bagan kendali dapat diketahui bahwa terdapat empat titik yang berada diluar batas pengendali atas dan oleh karena itu titik yang berada diluar kendali dihilangkan sehingga akan dicari batas kontrol yang baru (batas kontrol yang direvisi).

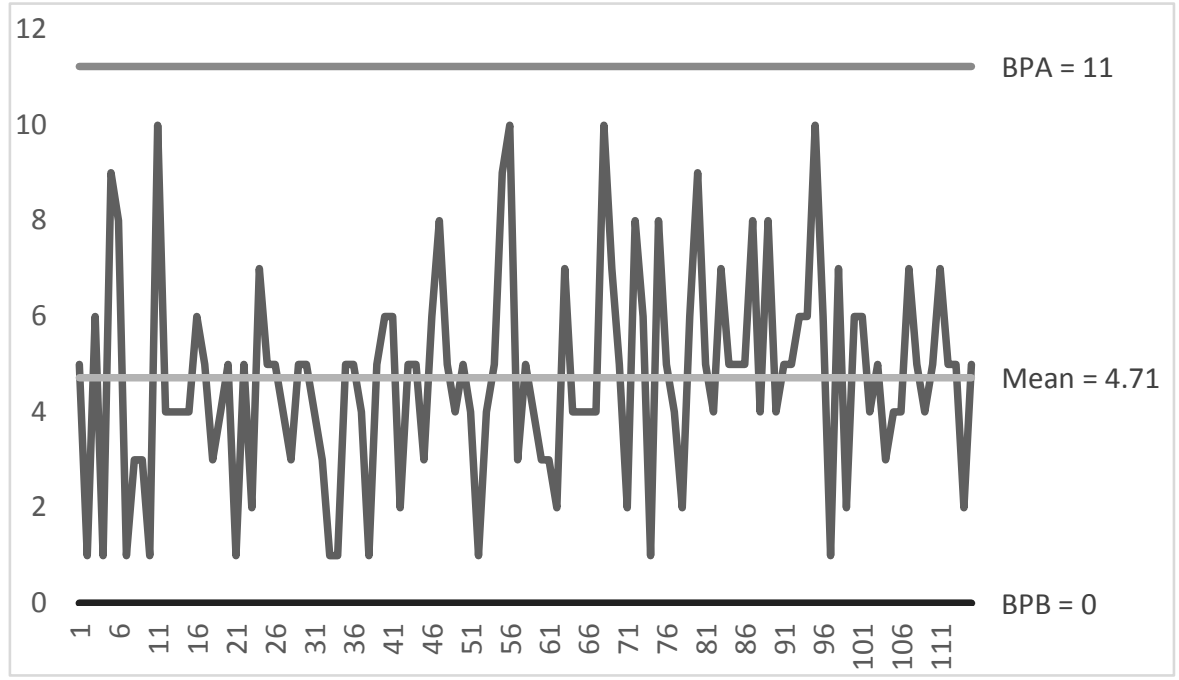

Gambar 4.5 Bagan Kendali C revisi pada data lama rawat inap pasien penyakit DBD di RS. Wahidin Sudirohusodo. 


\section{Elsa Resa Sari, Erna Tri Herdiana, Nasrah Sirajang}

Dari Gambar 4.5 dapat diketahui bahwa lama rawat inap pasien penyakit demam berdarah di RS. Wahidin Sudirohusodo dapat dirawat maksimal 11 hari, dan normalnya pasien penyakit demam berdarah dirawat selama kurang lebih 4 hari. Berdasarkan batas kendali untuk pasien rawat inap penderita penyakit DBD yang dirawat lebih dari 11 hari, maka pasien tersebut disarankan untuk melakukan pemeriksaan lebih lanjut.

Dari bagan kendali diatas diketahui bahwa tidak ada pasien yang berada diluar batas pengendali maka dapat disimpulkan bahwa lama rawat inap pasien penyakit demam berdarah di RS. Wahidin Sudirohusodo mulai bulan Januari 2005 sampai bulan Juli 2006 telah terkendali.

\section{Kesimpulan}

Berdasarkan hasil dan pembahasan, diperoleh kesimpulan sebagai berikut :

1. Bagan kendali atribut $\mathrm{C}$ yang terbentuk dengan menggunakan metode momen dalam menaksir parameter c adalah sebagai berikut

$$
\begin{aligned}
& B P A_{c}=[\bar{X}+K \sqrt{\bar{X}}] \\
& B P B_{c}=[\bar{X}-K \sqrt{\bar{X}}]
\end{aligned}
$$

2. Kinerja bagan kendali yang paling bagus untuk ukuran sampel yang berbeda menggunakan $m=\{10,20,50,100,200\}$ dan mean $c_{0}=\{5,10,15,30,50,70,100\}$ yaitu pada saat $c_{0}=5$ dan $\mathrm{m}=200$ karena memiliki nilai ARL yang terkecil.

3. Aplikasi bagan kendali pada data penderita penyakit demam berdarah di RS. Wahidin Sudirohusodo periode bulan Januari 2005 sampai bulan Juli 2006 yaitu normalnya pasien penyakit DBD dirawat selama kurang lebih 4 hari dan diperoleh nilai $B P A=11.22$ yang berarti bahwa pasien penyakit DBD dapat dirawat maksimal 11 hari.

\section{Daftar Pustaka}

[1] Adlaida, F. 2011. Penggunaan Model Regresi Zero-Inflated Generalized Poisson (ZIGP) Pada Data Penderita Penyakit Demam Berdarah (DBD) di Rumah Sakit Wahidin Sudirohusodo. Fakultas Matematika dan Ilmu Pengetahuan Alam. Skripsi. Universitas Hasanuddin, 


\section{Elsa Resa Sari, Erna Tri Herdiana, Nasrah Sirajang}

[2] Asri, M. 2015. Perbandingan Peta Kendali Atribut Dalam Pengendalian Kualitas Produk di PT. Arika Kharisma Agung. Fakultas Matematika dan Ilmu Pengetahuan Alam. Skripsi. Universitas Hasanuddin.

[3] Braun, W. J. 1999. Run Length Distribution For Estimated Attributes Charts. Journal Metrika. 50, pp. 121-129.

[4] Castagliola, P dan Wu, Shu. 2012. Design Of The c And np Charts When The Parameters Are Estimated. Journal IEEE Trans. Asia: World Scientific Publishing Company.

[5] Chakraborti, S dan Human, S.W. 2006. Parameter Estimation And Performance Of The P-Chart For Attributes Data. Journal IEEE Trans. Reliab. 55, pp. 559-566.

[6] Chakraborti, S dan Human, S.W. 2008. Properties and Performance Of The C-Chart For Attributes Data. J. Appl. Stat.

[7] Faizah, H. 2012. Perbandingan Bagan Pengendali Rata-Rata Bergerak dan Bagan Pengendali Rata-Rata Bergerak Geometri. Fakultas Sains dan Teknologi. Skripsi. Universitas Islam Negeri Maulana Malik Ibrahim.

[8] Fitriani, A. 2014. Diagram Kontrol Cumulative Sum Untuk Pengontrolan Proses dengan Model Autoregresive Orde Pertama $(A R(1))$. Skripsi. Bandung: Universitas Islam Bandung.

[9] Heizer, J dan Render, B. Manajemen Operasi (Edisi Ke-7). Jakarta: Salemba Empat. 2006.

[10] Irwan dan Haryono. 2015. Pengendalian Kualitas Statistik. Edisi Pertama. IKAPI: Alfabeta Bandung.

[11] Lumbono, H. 2007. Pengendalian Kualitas Produksi Garment di PT. Asrindo Indty Raya dengan Menggunakan Diagram Kontrol p. Fakultas Matematika dan Ilmu Pengetahuan Alam. Skripsi. Universitas Negeri Semarang.

[12] Montgomery, C. D. 1990. Pengantar Pengendalian Kualitas Statistik. Yogyakarta: Gadjah Mada University Press.

[13] Montgomery, C. D. 2009. Statistical Quality Control (6th ed). Asia: John Wiley \&Sons (Asia) Pte. Ltd.

[14] Walpole, R. E dan Myers, R.H. 1995. Ilmu Peluang dan Statistika Untuk Insinyur dan Ilmuwan. Edisi ke-4. Bandung: Institut Teknologi Bandung. 